\title{
Waste management costs in Greece: spatial patterns and causal factors
}

\author{
K. E. Lasaridi $^{1}$, A. Rovolis ${ }^{1}$ \& K. Abeliotis ${ }^{2}$ \\ ${ }^{I}$ Department of Geography, Harokopio University, Greece \\ ${ }^{2}$ Department of Home Economics and Ecology, \\ Harokopio University, Greece
}

\begin{abstract}
This paper attempts to estimate the municipal solid waste (MSW) management costs in a number of urban and rural municipalities in Greece. The dataset comprises 71 municipalities, covering about $30 \%$ of the total population of the country. The permanent population of the municipalities examined ranges from 39 (Antikythera) to 789,166 (Athens) people, according to the 2001 census data. Data on MSW production, collection, transport, recycling and disposal were collected, using questionnaires. The total waste management cost ranges from $€ 25 /$ tonne to $€ 948 /$ tonne, with a mean value of $€ 129 /$ tonne and median $€ 104 /$ tonne. Relatively increased costs are recorded in the municipalities of the Attica region due to the fees paid to AMCAR (Association of Municipalities and Communities of the Attica Region) for the landfilling of their waste, while several, especially rural, municipalities still use uncontrolled dumps not entailing any financial disposal costs. The collection and transport costs account on average for about $85 \%$ of the total costs, due to the lack of treatment and the generally low cost of final disposal in the country. Operational costs account for a little over $85 \%$ of the total cost, with labor costs being the major cost fraction. Most of the local authorities, especially in the urban areas, have developed economic sufficient systems of waste management, with the fees paid by the citizens covering their expenses; however, this does not mean that the notion of "economic efficiency" includes potential negative environmental externalities. The final part of the analysis presents some potential explanations for the spatial variation of municipal waste management costs.

Keywords: municipal solid waste (MSW), waste management costs, urban economics, economic geography, Greece, collection costs, disposal costs.
\end{abstract}




\section{Introduction}

Waste management costs depend on the geographic, demographic, economic and social characteristics of the area, as well as cultural issues, consumption habits and the national legal framework that may require specific levels of waste management services and treatment technologies (Tchobanoglous et al. [1]). As waste management is a labour intensive activity, especially with regard to waste collection and transport and street cleansing, the level of labour costs is a crucial determinant of the overall costs. However, within the same country, or among countries with similar GDP labour costs do not vary widely and other factors such as waste quantities produced, technologies utilised, quality and efficiency of the services provided, as well as the geographic and built environment characteristics become the determinant factors.

The implementation of policies aiming to the sustainable management of waste, often based on the so-called "waste management hierarchy" (reduce, reuse, recover before safe final disposal) is driving waste management costs to substantially higher levels. This is particularly true for those EU Member-States with less developed waste management systems, which will need to introduce large changes to their waste management practices in order to comply with the EU requirements (COM [2], EUNOMIA [3]). Most Mediterranean countries and new Member-States, as well as some of the most developed EU countries (e.g. the UK and to some extend Italy and France), fall under this category, facing great challenges to transform their waste management systems, while keeping cost increases to a minimum. In this context, it is particularly important to study the cost components of the existing waste management systems of Greek local authorities, to derive efficiency indicators and identify the factors affecting cost variations, in order to improve the economic efficiency of those systems and provide savings that will partially cover the expected cost increases. It is well established that solid waste management constitutes one of the major Municipal expenditures, globally. Moreover, little work has been carried out to investigate in which ways local authorities are responding to the new waste management agenda, being set by the EU and the corresponding national strategies.

The aim of this paper was to collect data on waste management practices and costs, calculate and analyse the different cost components (i.e. capital vs. operational, collection and transport vs. treatment and disposal) and identify possible causal factors of cost differentiation for a number of urban and rural municipalities in Greece, covering about $30 \%$ of its population.

\section{Data collection and analysis}

\subsection{Primary data collection}

Primary data were collected through a questionnaire survey of practically all the Municipalities of the Attica region and the largest two Municipalities of each Prefecture, carried out in the period 2/5/2005-30/4/2006. An open type questionnaire was sent via fax to 220 local authorities, following an initial 
telephone communication with the person responsible for the waste management service. A repeated telephone follow up was made and in many cases it was followed by a visit to the local authority. 71 questionnaires $(32.3 \%$ of the local authorities approached) were completed, corresponding to a population of approximately $3,100,000$ people or $28.3 \%$ of total country population (NSSG [4]).

The questionnaire used contained questions regarding: general data of the municipality; waste production, collection, transport, disposal and recycling; waste management infrastructure; number of personnel employed in the waste management service; and direct waste management financial data. Questions were designed to give the possibility to cross-check the data provided. Demographic data from the 2001 census were used (NSSG [4]).

\subsection{Waste generation rates and costs calculation}

An individual question on the waste quantities generated in and collected by the local authority (these two quantities considered identical) was included in the questionnaire, noting whether this was an estimate or a measured value through vehicle weighing at the landfill. If the value came from weighing data, this was used as given. Otherwise, the waste quantity was calculated on the basis of the weekly collection trips and capacity of each collection vehicle and cross-checked with the capacity of the temporary storage system. As most local authorities do not posses regular weighing sheet data (although they should, according to the legislation - Ministerial decree 29407/3508/2002, FEK 1572B) in many cases. If a variation of more than $15 \%$ was observed, the municipality was contacted for additional information and clarifications, which usually resolved the conflict. For the calculations a waste density of $0.43 \mathrm{t} / \mathrm{m}^{3}$ and $0.13 \mathrm{t} / \mathrm{m}^{3}$ in the vehicle and the bins was assumed, while both bins and vehicles are assumed to utilise $85 \%$ of their capacity, unless a different statement was clearly made in the questionnaire (Panagiotakopoulos [5], Tchobanoglous et al. [1]).

An extensive catalogue of potential costs was included in the questionnaire according to Panagiotakopoulos [5] and USEPA [6], which has been presented in Lasaridi et al. [7]. For the cost analysis of the municipal waste management systems, costs were classified into capital and operational cost. Each of these two categories was in turn classified into collection and transport cost (CTC) and disposal cost (DC). The requested information regarding the capital cost components included the date of their purchase / acquisition. The transformation of the capital cost into the Equivalent Annual Cost (EAC) was made considering there is no inflation and taking into account a depreciation rate (r) of $8 \%$ and a depreciation life span of each component of the system, as follows: 8 years for vehicles, other machinery and bins; 15 years for landfill mechanical equipment; and 30 years for the civil engineering works at the landfill (Ossenbruggen [8], Panagiotakopoulos [5]). Where necessary, typical literature and market data were used for missing cost components.

It is worth mentioning that the capital cost components of the disposal costs did not appear in many questionnaires, as most municipalities using sanitary landfills do so through their Associations, to which they pay an annual fee 
(operational cost). On the other hand, many of the local authorities not belonging to an Association still dump their waste, in sites not entailing many, if any, capital costs. Most Local Authorities (LAs) of Attica are members of the Association of Municipalities and Communities of the Attica Region (AMCAR), which owns the landfill of Ano Liosia and pay gate fees calculated as a percentage (currently $6 \%$ ) of their annual state subsidy, two years before the year of charging. Their waste disposal cost is therefore independent of the quantity of waste produced. However, an index of "disposal cost per ton" was calculated for comparison among LAs. Other landfills of the country charge on a waste quantity basis.

Questions on the rates of the waste charges for homes and stores/offices, as well as the total revenue of the LA from the waste charges, were also included in order to access the extent to which the calculated waste management cost are covered by the relevant revenue, which is actually demanded by law. In Greece waste charges are calculated on the basis of the surface area of the property, and are collected through the electricity bill, having no connection with the actual amount of waste produced within the property charged. Waste charges form the major part of the municipal charges, which also include street lighting. In this study waste charges were considered to cover $90 \%$ of the total municipal charges.

\section{Results and discussion}

\subsection{Waste management in Greece: a brief overview}

Greece has a population of 10,934,097 according to the 2001 census and an area of 132,000 square kilometres. The urban population counts roughly 6 million or $59 \%$ of the population. The population density is 79 people per $\mathrm{km}^{2}$, half the EU average, while more than one third of the total population lives in the Greater Athens Area (Attica). The annual MSW production is estimated at 4,559,000 tonnes for 2001 and has been increasing at about 3\% annually during the last decade, closely following the GDP growth. The national average waste composition according to the official data is: putrescibles, $47.0 \%$; paper and cardboard, 20.0\%; glass, 4.5\%; plastics, $8.5 \%$; metals, $4.5 \%$; and various, $15.5 \%$. MSW are mainly disposed of in landfills $(91.2 \%$; of it, about $40 \%$ is disposed of to uncontrolled dumps or licensed sites with insufficient environmental protection measures, which need to be phased out and restored by the end of 2007). The rest $8.8 \%$ is recycled through both the formal and informal sectors, while the existing MBT (mechanical-biological treatment) capacity is not currently in full use (Anon [9]). A more detailed presentation of the solid waste management status in Greece can be found in Lasaridi [10].

\subsection{Waste production rate and management costs at the municipal level}

The demographic characteristics and the annual waste production rate of the LAs examined are presented in table 1. The permanent population of the LAs examined ranges from 39 (Antikythera) to 789,166 (Athens) people (2001 census). 
Table 1: Demographic characteristics and waste generation rate (WGR) in the local authorities examined.

\begin{tabular}{|c|c|c|c|c|c|}
\hline Municipality & $\begin{array}{l}\text { Popula- } \\
\text { tion }\end{array}$ & $\begin{array}{c}\text { WGR } \\
(\mathrm{kg} / \mathrm{ca} / \mathrm{yr})\end{array}$ & Municipality & $\begin{array}{l}\text { Popula- } \\
\text { tion }\end{array}$ & $\begin{array}{c}\text { WGR } \\
(\mathrm{kg} / \mathrm{ca} / \mathrm{yr})\end{array}$ \\
\hline Athens & 789,166 & 648 & Moudania & 16,236 & 1,000 \\
\hline Peristeri & 146,743 & 995 & Nea Erythrea & 15,972 & 933 \\
\hline Larisa & 132,779 & 462 & Papagou & 13,799 & 846 \\
\hline Kallithea & 115,150 & 449 & Thasos & 13,451 & 1,241 \\
\hline Nikaia & 95,798 & 476 & Almyros & 13,198 & 452 \\
\hline Zographou & 81,435 & 538 & Paiania & 12,997 & 805 \\
\hline Helioupoli & 81,024 & 760 & Herakleia Serron & 12,982 & 410 \\
\hline Keratsini & 78,474 & 596 & Mandra & 12,739 & 588 \\
\hline Aegaleo & 77,917 & 475 & Egina & 12,716 & 668 \\
\hline Nea Smyrni & 76,508 & 572 & Vari & 10,702 & 1,309 \\
\hline Ioannina & 75,550 & 467 & Servioi Kozanis & 9,512 & 384 \\
\hline Xalandri & 75,327 & 688 & Amfissa & 8,864 & 620 \\
\hline Amarousion & 71,551 & 485 & Karpenisi & 8,736 & 1,000 \\
\hline Korydallos & 70,710 & 490 & Lykovrisi & 8,426 & 1,009 \\
\hline N. Ionia & 69,508 & 788 & $\begin{array}{l}\text { Ellispontos } \\
\text { Kozanis }\end{array}$ & 7,481 & 334 \\
\hline Ag. Demetrios & 68,719 & 743 & Molos & 5,926 & 404 \\
\hline Palaio Faliro & 67,160 & 771 & Ekali & 5,497 & 910 \\
\hline Galatsi & 63,418 & 582 & Eresos-Antissis & 5,111 & 402 \\
\hline Lamia & 62,452 & 643 & Dionysos & 5,032 & 725 \\
\hline Ag. Paraskevi & 60,065 & 571 & Mastichochoria & 4,322 & 639 \\
\hline Petroupoli & 51,559 & 474 & $\begin{array}{l}\text { Thouria } \\
\text { Messinias }\end{array}$ & 3,690 & 352 \\
\hline Kozani & 49,812 & 404 & Ithaki & 3,212 & 1,156 \\
\hline Haidari & 48,494 & 351 & $\begin{array}{l}\text { Apollonio } \\
\text { Lefkadas }\end{array}$ & 3,065 & 320 \\
\hline $\begin{array}{l}\text { Heraclio } \\
\text { Attikis }\end{array}$ & 48,132 & 951 & $\begin{array}{l}\text { Margaritio } \\
\text { Thesprotias }\end{array}$ & 2,819 & 284 \\
\hline Argyroupoli & 35,076 & 427 & Afidnai Attikis & 2,422 & 768 \\
\hline Holargos & 33,915 & 552 & Rodopoli Attikis & 2,048 & 633 \\
\hline Aspropyrgos & 27,927 & 715 & $\begin{array}{l}\text { Feneos } \\
\text { Korinthou }\end{array}$ & 2,019 & 180 \\
\hline Metamorphosi & 27,522 & 1,194 & East Zagorio & 1,814 & 83 \\
\hline Kessariani & 27,193 & 604 & Herakleia Artas & 1,672 & 200 \\
\hline Voula & 25,647 & 527 & Sellon Ioannina & 1,402 & 407 \\
\hline Daphne & 25,058 & 583 & $\begin{array}{l}\text { Ano Pagonio } \\
\text { Ioannina }\end{array}$ & 1,398 & 715 \\
\hline Theva & 24,443 & 900 & Agrafa & 1,237 & 95 \\
\hline Moschato & 24,315 & 1,051 & Oropos Attikis & 1,224 & 1,460 \\
\hline Pefki & 20,894 & 443 & Kommeno Artas & 665 & 451 \\
\hline $\begin{array}{l}\text { Ag. Nikolaos, } \\
\text { Crete }\end{array}$ & 19,593 & 1,100 & Antikithira & 39 & 1,282 \\
\hline Tyrnavo & 17,401 & 438 & Moudania & 16,236 & 1,000 \\
\hline
\end{tabular}


The annual waste generation rate (WGR) varies significantly between the different municipalities examined, from just $83 \mathrm{~kg} / \mathrm{ca} / \mathrm{yr}$ (i.e. $0.23 \mathrm{~kg} / \mathrm{ca} / \mathrm{d}$ ) for East Zagorio, Epirus, to $1,309 \mathrm{~kg} / \mathrm{ca} / \mathrm{yr}$ (i.e. $3.59 \mathrm{~kg} / \mathrm{ca} / \mathrm{d}$ ) for Vari, Attica, with a mean and median value of 644 and $588 \mathrm{~kg} / \mathrm{ca} / \mathrm{yr}$, respectively. The municipalities recording high annual waste production per capita, above 1 tonne/ca/yr are: Metamorphosi, Lykovrisi and Moschato, in Athens, which have an industrial activity; Thasos, Antikithira, Ithaki, Moudania and Ag. Nikolaos, all with a heavy tourist flow compared to their permanent population; Vari and Oropos, which experience a fast population growth, therefore possibly having a higher population than that recorded in the census; and Karpenisi, which does not fall into any of the above categories. LAs with affluent population often have relatively high WGR (e.g. Ekali, Dionysos, Palaio Faliro, Papagou) but this does not apply in all cases (e.g. Amarousion, Voula). Thus, on the basis of the qualitative results of this study, the economic and social composition of the sample's municipalities does not determine WGR in absolute terms.

A clearer picture appears if we look into the bottom of this classification: the last five places, corresponding to WGR below $300 \mathrm{~kg} / \mathrm{ca} / \mathrm{yr}($ i.e. $<0.80 \mathrm{~kg} / \mathrm{ca} / \mathrm{d}$ ) are all taken up by rural, small (1000-3000 people) and often mountainous municipalities (East Zagorio, Agrafa, Feneos-Korinthou, Hrakleia-Artas and Margaritio-Thesprotias). In this case, it seems that the geographic-economicsocial composition of the municipalities does determine waste production per capita, with prominent parameter their rural character.

The variation of the daily WGR with population is better illustrated in fig. 1a, where the sample mean WGR together with the upper and lower control limits (UCL and LCL, respectively) at 95\% confidence level (i.e. 2- $\sigma$ control) are depicted, (Psoinos [11]). Variations is much more pronounced in small LAs, while for populations over 50,000 people WGR tends to fall fairly close to its mean value of $1.76 \mathrm{~kg} / \mathrm{ca} / \mathrm{d}$, which is much higher than the officially reported national mean of $1.14 \mathrm{~kg} / \mathrm{ca} / \mathrm{d}$. All the LAs were within the LCL, while 3 were above the UCL (Thasos, Antikithira, Vari).

There is also significant differentiation between municipalities in the cost of MSW management (fig. 1b,c). Total cost varied widely from $27 € /$ t (Kommeno Artas \& Herakleia Artas) to $948 € / \mathrm{t}$ (Ano Pagonio) with a mean value of $138 € / \mathrm{t}$, which was very close to the cost for Athens $(116 € / t)$, for which data may be considered reliable due to previous extensive studies of the capital's waste management system. There were three LAs (Feneos, East Zagorio \& Agrafa) above the UCL, all small rural communities with much dispersed population, while none was below the LCL. On per capita basis, annual costs varied from $5 € /$ ca (Herakleia Artas) to $679 € /$ ca (Oropos) with a mean value of $77 € / \mathrm{ca}$, again very close to that of Athens $(75 € / \mathrm{ca})$. Only two municipalities exceeded the UCL (Oropos and Vari), which had high WPR possibly attributed to their fast population growth, leading to an underestimation of their current population by the 2001 census data. Again, cost dispersion is wider in small LAs and tends to narrow down above a population of 3000 people.

Moreover, there are some significant differences regarding the components of total cost across the different municipalities (data not shown). 



Figure 1: Variation of the (a) waste generation rate; (b) mean annual waste management cost per tonne of waste produced; and (c) mean annual waste management cost per capita, in the municipalities examined with population size. The solid and dashed lines denote the sample mean and the $95 \%$ control limits, respectively (UCL and LCL). 
Some municipalities appear to have high capital costs, in itself an indication that there was significant investment in recent years, in many cases as a side effect of the organisation of the Olympic Games 2004 (e.g. Athens, Amarousion). In any case, the most important component of waste cost in capital and operational cost appears to be the latter, with a mean sample value over $86 \%$. This is expected to a large extend, as waste management is a labour intensive service. Moreover, in Greece waste management is confined to collection and landfilling or dumping, lacking the more capital intensive options of treatment (biological and/or thermal). As EU policy drives waste management towards that direction this is expected to change by 2010 , increasing capital and overall costs (COM [2]).

More interesting findings seems to be those from the second breakdown of total waste cost, in collection and transport cost on the one hand and final disposal cost on the other, with the former representing over $85 \%$ of the total costs for the sample. Bearing in mind that a large number of the examined LAs, compared to the national average, are served by organised landfills, this percentage might be lower than the country average (Lasaridi et al. [7]). Ten municipalities, constituting $14 \%$ of the sample, appeared to have only collection and transport costs, disposing their waste to licensed or unlicensed dumps. In many cases land costs have not been included in the disposal costs, as the land used belonged to the LA and no data were provided on its area and/or land cost in the surroundings. This is informative of the way LAs calculate their costs, taking various, potentially expensive components for free if they did not entail a direct monetary flow, in contrast to generally accepted guidelines (Anon [12], Boli and Tarcq [13]).

As many local authorities in Greece do not keep reliable waste management data (including records of daily weight sheets) and the organisational level of their waste management services may vary, some data collected from certain municipalities, and therefore the respective derived waste generation rate and cost estimates, should be treated with care. However, this does not restrict the value of the current research, as useful trends have been recorded and causal factors could be identified, to a large extent, for the variations observed and most of the outliers. Moreover, it should be noted that, given the lack of official records, the data used for the Regional Waste Management Plans are of no better quality than those derived in this study, as often they rely on generally admitted (but thinly ground) waste generation rates which may not apply to all the municipalities of the Region. A recent study on the MSW composition and production in the island of Crete arrived at similar results, that the waste generation rates used in the Regional Plan may be underestimated (Gidarakos et al. [14]).

Moreover, one of the main drawbacks of any waste management cost estimate at the local authority level in Greece is that it is not always clear how many of the personnel officially belonging to the waste management service of the authority actually work there. This problem stems from the practice of many local authorities to hire people for the waste management services in order to cover various personnel needs. This means that many of these employees will 
eventually end up working in a different department within the local administration while they will be classified as being employed in waste management. Furthermore, this also represents a long established clientelistic approach practiced across the range of local government in Greece, whereby people are recruited by the municipality in return for their vote.

\section{Conclusions}

Several policy issues arise in the light of the paucity of data and the empirical findings that show significant discrepancies in waste generation rates and management costs between different municipalities in Greece. A current trend in the waste management services worldwide is the evaluation of the performance either of each waste service component separately or of the overall system. Benchmarking is widely spread in the evaluation of business performance and recently appears to be promoted also in the evaluation of public/municipal services, (Anon [12], Boli and Tarcq [13]). Benchmarking of waste services is a tool for evaluating and comparing waste services of a specific municipality over time, as well as comparing different municipalities for the same reference year. Of course, benchmarking does not refer only to cost indicators, as different levels of service entail different costs. A municipality, for example, supporting an extensive source separation system is expected to have higher collection costs compared to another system which is offering only the standard commingled waste collection and disposal to an uncontrolled dump. The latter is cheaper (in short term monetary costs) compared to a well operated landfill and even more, compared to an integrated MSW system offering biological or thermal treatment of the waste. Therefore, differences in cost indicators such as cost per ton, per person or per household do not necessary reflect differences in the efficiency of service provision. However, all local authorities examined in this study offer the "standard" for Greece package of waste management services, which consists of waste collection, transport and land disposal, to a sanitary landfill or a dump. In this respect, cost differences may reflect to some extend a variation in service efficiency, the rest being explained by various geographic and demographic factors.

\section{Acknowledgements}

This research was supported in part by Pythagoras II programme (MIS: 97456, subproject 1) co-funded by the European Social Fund $(75 \%)$ and National Resources $(25 \%)$. Thanks are due to Mr Dalakas for developing the data mining routines from the municipalities' database.

\section{References}

[1] Tchobanoglous, G., Theisen, H. \& Vigil, S., Integrated Solid Waste Management: Engineering Principles and Management issues, McGrawHill, Inc.: New York, 1993. 
[2] COM, Report from the Commission to the Council and the European Parliament on the national strategies for the reduction of biodegradable waste going to landfills pursuant to Article 5(1) of Directive 1999/31/EC on the landfill of waste, COM (2005) 105 final: Brussels, 30-3-2005.

[3] EUNOMIA, Costs for Municipal Waste Management in the EU, Final Report to Directorate General Environment, European Commission, 2002.

[4] NSSG (National Statistical Service of Greece), 2001 population census of Greece, 2001.

[5] Panagiotakopoulos, D., Sustainable Management of Municipal Solid Waste. ZYGOS publishers: Thessaloniki, 2002 (in Greek).

[6] USEPA, Full Cost Accounting for Municipal Solid Waste Management: A Handbook, Solid Waste and Emergency Response 5305W, EPA 530-R95-041, September 1997.

[7] Lasaridi, K., Komilis, D. \& Rovolis, A., Comparative analysis and geographic differentiation of solid waste management costs in urban and rural municipalities. Proc. of the $7^{\text {th }}$ Pan-Hellenic Geographic Conference of the Hellenic Geography Society, Lesvos, 14-17 October 2004 (in Greek).

[8] Ossenbruggen, P., Fundamental principles of Systems Analysis and Decision-Making, John Wiley \& Sons: New York, 1994.

[9] Anon, H.П. 50910/2727/2003, Hellenic Official Gazette, B1909, Measures and Terms for the Management of Solid Waste. National and Regional Management Planning, 2003 (in Greek).

[10] Lasaridi, K.E., Implementing the landfill directive in Greece: problems, perspectives and lessons to be learned. Proc. of the $5^{\text {th }}$ Int. Conf. ORBIT 2006 "Biological Waste Management: from Local to Global", Weimar 13-15 September 2006.

[11] Psoinos D., Implemented Statistics. Zitis Publications, Thessaloniki, 1989 (in Greek).

[12] Anon, Her Majesty's Government - Office of the Deputy Prime Minister, 2003. Guidance on best value performance for 2002/03. www.ukonline.gov.uk.

[13] Bolli, A. \& Tarcq, E., Environmental benchmarking for local authorities: from concept to practice. International Institute for Industrial Environmental Economics, Lund University, Sweden. European Environment Agency, Environmental Issues Report, No. 20, 2001.

[14] Gidarakos, E., Havas, G. \& Ntzamilis, P., Municipal solid waste composition determination supporting the integrated solid waste management system in the island of Crete. Waste Management, 26, pp. 668-679, 2006. 